\title{
COMPETITIVE ADVANTAGES AND BARRIERS IN INTERNATIONAL CONSTRUCTION: AN ORIGIN-HOST MARKET APPROACH
}

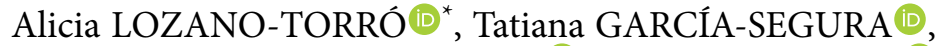 \\ Laura MONTALBÁN-DOMINGO®D, Eugenio PELLICER $\mathbb{}$ \\ School of Civil Engineering, Universitat Politècnica de València, Camino de Vera s/n, 46022 Valencia, Spain
}

Received 22 May 2019; accepted 08 October 2019

\begin{abstract}
The growing importance of international construction activity forces companies to find out what competitive advantages to provide and barriers to overcome to achieve success, considering the particular characteristics of their origin and destination countries. Seventy six articles regarding success in the international construction market in the period 2008-2017 are reviewed to identify the barriers and the competitive advantages that most affect the international success of contractors. The Chi-Square $\left(\chi^{2}\right)$ statistical test is used to verify the influence of the origin and destination countries on these variables. The literature identifies the provision of trained human resources as the most important competitive advantage and cultural differences and political risks as the main barriers. The Chi-Square $\left(\chi^{2}\right)$ test indicates a dependency relationship between the origin country and the competitive advantage "managerial ability" to achieve international success, and between the external barriers "link between countries", "political environment" and "economic environment" with the target market. Results of this paper provide valuable information for any construction company seeking international success.
\end{abstract}

Keywords: international construction market, competitive advantages, barriers, success, origin country, host country.

\section{Introduction}

The growth of the international construction market in the last decades (Zhao et al., 2017) has generated new opportunities for contractors (Lee et al., 2016). The 21st century context, characterized by advanced technology, rapid communication and transport, integrated markets, and commercial liberalization, has fueled this expansion (Ye et al., 2009). Likewise, the key role of sustainability in today's society, the priority of advanced economies to improve infrastructures in developing countries (DiazSarachaga et al., 2017; Sierra et al., 2017) as well as the rise in the next decades of urbanization levels in the main areas of development (Diaz-Sarachaga et al., 2016; Sierra et al., 2018) are factors that also contribute to the increase of the international construction activity.

To benefit from these opportunities contractors have to acquire knowledge of the variables that influence international activity, being competitive advantages and barriers two of the key variables involved. According to Price and Newson (2003), a company acquires a competitive advantage when it is superior to its rivals in terms of attracting customers and defending itself against compe- tition. Competitiveness is related to success because it is an attribute of a construction company that allows it to achieve success and long-term growth in a competitive environment (Zich, 2014). Likewise, international contractors have to offer certain competitive advantages to adapt to unknown and distant environments with a shortage of skilled human resources as well as multicultural teams with language differences and power-distance (Mosley \& Bubshait, 2016) that can affect the cost or term of projects or generate misunderstandings (Lee et al., 2011). In contrast, barriers are considered environmental factors - political, economic, technological, and social environments (Belassi \& Tukel, 1996) - that involve differences in political and legal systems, social norms and values, cultural backgrounds, and project environments that companies have to face because of their influence on international performance (Han et al., 2007; Park et al., 2014).

In parallel with the growth of the international construction market, internationalization in the construction industry is considered one of the most relevant research areas in construction management literature, and the

${ }^{*}$ Corresponding author. E-mail: allotor@upv.es 
number of related publications about it has increased since the 1990s (Gundes \& Aydogan, 2016). Authors have focused on strategies to enter the foreign markets, decision models for construction companies, risk assessment and international construction joint ventures (ICIVs) (Gunhan \& Arditi, 2005). Other topics of focus have been competence and performance, knowledge management, and decision making, although interest in this area declined from 2011-2014 (Utama et al., 2016). Likewise, although the research areas of success factors and barriers address important issues, they were neglected between 1995 and 2014; therefore, future research needs to be carried out in these areas (Utama et al., 2016). Literature reviews related to internationalization in the construction sector evaluate trends and map the productivity in the field by analyzing journals, research contributions of each country and institute, most frequently cited papers, and most important research topics (Gundes \& Aydogan, 2016). Research methodologies are also identified in these papers, with company questionnaires and interviews being two of the most commonly used methods (Utama et al., 2016). However, these publications do not examine the main competitive advantages and barriers for the companies interviewed even though these issues are currently some of the most essential to explore (Utama et al., 2016).

Another aspect to consider is the influence of the origin and destination countries of the companies in their international activity. Specific advantages of the origin country can encourage companies to access foreign markets; governments can stimulate internationalization through motivation and commercial assistance (Awil \& Abdul-Aziz, 2005), and the development and competitiveness of an industry can boost the internationalization of companies (Sakakibara \& Porter, 2001). Therefore, there is a correlation between the level of economic development of a country and foreign direct investment abroad (Liu et al., 2005). Additionally, Dunning (2000) identified property advantages of international companies as capabilities that benefit primarily from the resources and capabilities of their origin countries, enabling companies to achieve higher performance in the international market (Yang et al., 2015). With respect to the influence of the destination country on the internationalization success, companies that access it must face political, legal, social and cultural changes that can affect the performance of their construction projects (Han et al., 2007; Park et al., 2014). Moreover, the construction industry is sensitive to the characteristics of the host country because its production is based on projects and is oriented to a specific location (Lee et al., 2016). Another study that supports this idea states that once a company has acquired tacit knowledge of a specific country, it is easier to continue working in this country than in others that have new barriers and institutional differences (Jung et al., 2010); therefore, it is essential to carry out an analysis of the host market before embarking on an international project to obtain a greater understanding of the risks that may undermine the project's success (Alashwal et al., 2017).
In spite of the importance of the origin country and destination market in the international success of companies, the relationship between competitive advantages and the origin country and between barriers and the target market has not been addressed yet; thus, a holistic approach is required to analyze the literature in an effort to deepen the characterization of the competitive advantages and barriers that determine the internationalization success of the contractors. This analysis will help companies to understand the process and to establish strategies that promote better results from their internationalization considering the origin country of the company and the country where this is to be implemented.

To cover this knowledge gap, this paper focuses on the following research goals: (G1) to determine the competitive advantages that have the most influence on the international performance of the companies; (G2) to identify the barriers that pose the greatest threat to obtaining the international success of companies; (G3) to determine if there are relationships between competitive advantages and origin countries; and (G4) to detect if there are relationships between barriers and target markets.

To achieve these goals, the paper is structured as follows. First, the research method is explained, based on a bibliometric review and the use of the Chi-Square $\left(\chi^{2}\right)$ test as statistical analysis. Subsequently, results are presented in relationship to the origin countries and destination markets of the companies, the main competitive advantages and the greater barriers that influence their international success, and the results of the statistical analysis that proves the relationship between these variables. Finally, conclusions of the paper are described together with limitations, recommendations, and future lines of research.

\section{Research method}

This study followed an overall research method divided into two phases, summarized in Figure 1. In the first phase, a literature review of 76 papers from the period of 2008-2017 was carried out to determine, through a quantitative analysis, the number of papers per year and the origin and destination countries of the companies. Subsequently, a qualitative analysis was developed to identify the main competitive advantages and barriers for these companies to achieve success. These variables were then grouped into categories by affinity criteria (Carnevalli \& Miguel, 2008). In the second phase, the Chi-Square Test $\left(\chi^{2}\right)$ was performed to check if there are relationships between the competitive advantages identified and the origin country of the companies, and among the greater barriers according to the target market.

In the bibliometric analysis, data were obtained from the Web of Science (WOS) database. The search for scientific articles in WOS was carried out by defining a strategy with the following keywords: TI $=$ (globalization OR globalisation OR internationalization OR internationalisation OR international) $\mathrm{AND} T \mathrm{TI}=$ (construction OR construction industry $\mathrm{OR}$ engineering $\mathrm{OR}$ infrastructure 


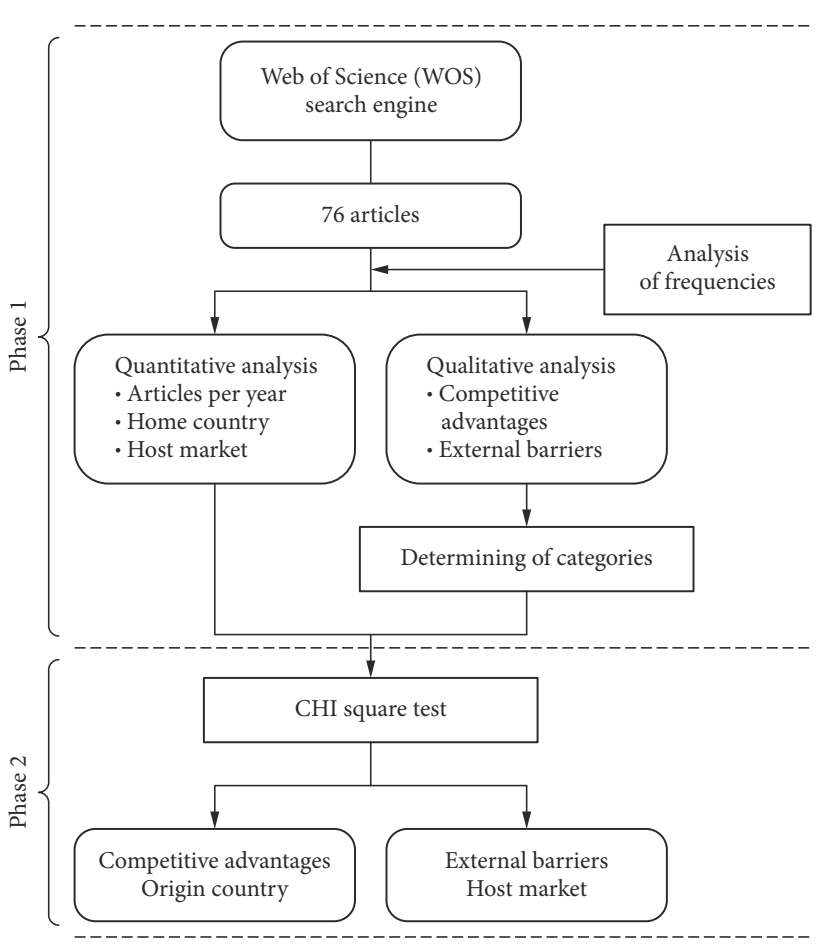

Figure 1. Flow chart of study

OR project OR contractor OR building) AND TS $=$ (construction OR building), and by limiting the Document Type to "article" or "review" or "editorial" in English, the Research Domains to "science technology" or "social sciences" and the Research Area to "engineering" or "business economics" or "construction building technology" or "public administration" or "architecture". A total of 466 articles were obtained as a result of this search. Later, a refinement of results was carried out, narrowing the scope to papers published in the period of 2008-2017 that dealt with international success in the construction sector. After this filtering, the number of papers included in the study was reduced to 76 .

A first analysis, carried out by the first author, focused on collecting the following information for each one of the 76 articles: year of publication, country of origin of the companies analyzed, destination commercial areas, and competitive advantages and barriers that have the greatest influence on the international success of the companies. To fulfil the requirements of the systematic reviews and validate the results of the first reading, the articles were read again by another of the authors (Burnard, 1991; Polit \& Beck, 2004; Bryman, 2016). The information associated with the year of publication, country of origin of the companies and destination commercial areas was analyzed quantitatively to define the number of papers per year in the study period (2008-2017) and the number of papers that include a specific origin country or destination area. To cover the first and second objectives the information associated with the competitive advantages and barriers extracted from the articles was analyzed qualitatively following a bottom-up approach (Burnard, 1991; DowneWamboldt, 1992; Dey, 2003). Firstly, using an inductive process, the information collected about barriers and competitive advantages was clustered in variables (Essl \& Mauerhofer, 2018); secondly, the variables were aggregated in categories using the affinity technique (Carnevalli \& Miguel, 2008). This technique, also known as the KJ grouping method (Mizuno, 1993), organizes data by affinity, and it was used to group the main competitive advantages and barriers in a hierarchical way. Finally, the frequency of articles that consider each variable was determined, and a statistical analysis based on a Chi-Square $\left(\chi^{2}\right)$ test was applied to achieve the next goals of the study: to analyze the relationships between the main competitive advantages and the origin country of the companies and between the main barriers and the host market. This type of statistical analysis is the most often used for categorical data analysis (Xia et al., 2012).

\section{Quantitative analysis}

The results of the quantitative analysis are presented in this section. Table 1 provides the number of papers published between 2008 and 2017. From 2008 to 2012, there was a pronounced decrease in the number of articles related to success in international construction, going from 11 in 2008 to only 1 publication in 2012. This period coincides with the global financial crisis that began in 2008, and the decreasing trend of papers partially confirms the results obtained by Utama et al. (2016), who noted that the interest in research on performance declined from 2011-2014. Starting in 2012, the number of publications followed a growing trend until reaching a peak of 15 articles in 2016 and falling, again, in 2017 to 8 . The resulting average per year is 7.6 publications.

The origin country of the internationalized companies was also identified in the papers. Furthermore, countries were grouped by commercial zones: Asia, Africa, Europe, the Middle East, North America, and Australia and New Zealand. Publications that did not indicate the origin country of the companies were grouped as "Not Specified". This group also includes articles that analyze companies considered in the American magazine Engineering News Record [ENR] (2017), in which the origin country is not indicated. Table 2 shows the number of articles per year that include a specific origin country of the companies, as well as the total number of articles and the percentage in the study period. When an article analyzes 2 or more $(x)$

Table 1. Number of articles published in the period 2008-2017

\begin{tabular}{|l|c|c|c|c|c|c|c|c|c|c|}
\hline Year & 2008 & 2009 & 2010 & 2011 & 2012 & 2013 & 2014 & 2015 & 2016 & 2017 \\
\hline Number of papers & 11 & 8 & 7 & 3 & 1 & 7 & 6 & 10 & 15 & 8 \\
\hline
\end{tabular}


countries, each country is considered in Table 2 to be $1 / 2$ or $1 / x$, respectively. Table 3 results from the grouping of countries in Table 2 into commercial areas, obtaining the annual number of articles that include each commercial area. The results shown in Tables 2 and 3 indicate that the main commercial area is Asia (42.1\%), highlighting articles that analyze companies from China (21.1\%), South Korea (8.3\%), and Malaysia (5.2\%). It is followed by articles that do not identify the country (24.9\%), papers from the Middle East (14.2\%) that contain the articles about Turkish companies, and papers from Europe $(11.6 \%)$, represented mainly by companies in the United Kingdom (3\%).

These results are validated by the content of the articles of the literature review: Chinese construction industry is one of the largest and fastest-growing markets in the

Table 2. Home country of the companies

\begin{tabular}{|c|c|c|c|c|c|c|c|c|c|c|c|c|}
\hline \multirow{2}{*}{ Home Country } & \multicolumn{10}{|c|}{ Year of publication } & \multirow{2}{*}{ Total } & \multirow{2}{*}{$\%$} \\
\hline & 2017 & 2016 & 2015 & 2014 & 2013 & 2012 & 2011 & 2010 & 2009 & 2008 & & \\
\hline Not specified & 2.0 & 6.3 & 6.0 & 0.0 & 2.0 & 0.0 & 0.0 & 0.3 & 1.0 & 1.5 & 19.0 & 24.9 \\
\hline China & 3.0 & 2.4 & 1.2 & 2.0 & 2.0 & 0.0 & 1.0 & 0.5 & 3.0 & 1.0 & 16.1 & 21.1 \\
\hline Turkey & 1.0 & 0.0 & 1.0 & 1.3 & 1.0 & 0.0 & 1.0 & 1.0 & 2.0 & 2.5 & 10.8 & 14.2 \\
\hline South Korea & 0.0 & 1.4 & 1.0 & 0.0 & 1.0 & 1.0 & 0.0 & 1.0 & 0.0 & 1.0 & 6.4 & 8.3 \\
\hline Malaysia & 1.0 & 0.0 & 0.0 & 0.0 & 1.0 & 0.0 & 1.0 & 1.0 & 0.0 & 0.0 & 4.0 & 5.2 \\
\hline USA & 0.1 & 0.5 & 0.2 & 0.5 & 0.0 & 0.0 & 0.0 & 0.3 & 0.3 & 1.4 & 3.2 & 4.2 \\
\hline United Kingdom & 0.0 & 0.1 & 0.0 & 0.5 & 0.0 & 0.0 & 0.0 & 1.0 & 0.0 & 0.7 & 2.3 & 3.0 \\
\hline Japan & 0.1 & 0.2 & 0.0 & 0.3 & 0.0 & 0.0 & 0.0 & 0.3 & 1.0 & 0.2 & 2.1 & 2.8 \\
\hline Thailand & 0.0 & 0.0 & 0.0 & 0.0 & 0.0 & 0.0 & 0.0 & 0.5 & 0.0 & 1.0 & 1.5 & 2.0 \\
\hline France & 0.1 & 0.2 & 0.2 & 0.0 & 0.0 & 0.0 & 0.0 & 0.0 & 0.0 & 0.7 & 1.2 & 1.6 \\
\hline Singapore & 0.0 & 0.1 & 0.0 & 0.0 & 0.0 & 0.0 & 0.0 & 0.5 & 0.0 & 0.5 & 1.1 & 1.5 \\
\hline Germany & 0.1 & 0.2 & 0.2 & 0.0 & 0.0 & 0.0 & 0.0 & 0.0 & 0.3 & 0.2 & 1.0 & 1.3 \\
\hline Nigeria & 0.0 & 1.0 & 0.0 & 0.0 & 0.0 & 0.0 & 0.0 & 0.0 & 0.0 & 0.0 & 1.0 & 1.3 \\
\hline Denmark & 0.0 & 0.0 & 0.0 & 1.0 & 0.0 & 0.0 & 0.0 & 0.0 & 0.0 & 0.0 & 1.0 & 1.3 \\
\hline Taiwan & 0.0 & 0.0 & 0.0 & 0.0 & 0.0 & 0.0 & 0.0 & 1.0 & 0.0 & 0.0 & 1.0 & 1.3 \\
\hline Spain & 0.1 & 0.6 & 0.2 & 0.0 & 0.0 & 0.0 & 0.0 & 0.0 & 0.0 & 0.0 & 0.9 & 1.2 \\
\hline Austria & 0.0 & 0.6 & 0.0 & 0.0 & 0.0 & 0.0 & 0.0 & 0.0 & 0.0 & 0.0 & 0.6 & 0.8 \\
\hline Czech Republic & 0.0 & 0.5 & 0.0 & 0.0 & 0.0 & 0.0 & 0.0 & 0.0 & 0.0 & 0.0 & 0.5 & 0.7 \\
\hline Portugal & 0.0 & 0.5 & 0.0 & 0.0 & 0.0 & 0.0 & 0.0 & 0.0 & 0.0 & 0.0 & 0.5 & 0.7 \\
\hline Australia & 0.0 & 0.2 & 0.0 & 0.0 & 0.0 & 0.0 & 0.0 & 0.0 & 0.0 & 0.2 & 0.4 & 0.5 \\
\hline Canada & 0.1 & 0.0 & 0.0 & 0.0 & 0.0 & 0.0 & 0.0 & 0.0 & 0.0 & 0.3 & 0,4 & 0.5 \\
\hline Libya & 0.0 & 0.0 & 0.0 & 0.3 & 0.0 & 0.0 & 0.0 & 0.0 & 0.0 & 0.0 & 0.3 & 0.4 \\
\hline Greece & 0.1 & 0.0 & 0.0 & 0.0 & 0.0 & 0.0 & 0.0 & 0.0 & 0.0 & 0.0 & 0.1 & 0.1 \\
\hline New Zealand & 0.1 & 0.0 & 0.0 & 0.0 & 0.0 & 0.0 & 0.0 & 0.0 & 0.0 & 0.0 & 0.1 & 0.1 \\
\hline Italy & 0.1 & 0.0 & 0.0 & 0.0 & 0.0 & 0.0 & 0.0 & 0.0 & 0.0 & 0.0 & 0.1 & 0.1 \\
\hline Finland & 0.0 & 0.0 & 0.0 & 0.0 & 0.0 & 0.0 & 0.0 & 0.0 & 0.3 & 0.0 & 0.3 & 0.3 \\
\hline Russia & 0.0 & 0.0 & 0.0 & 0.0 & 0.0 & 0.0 & 0.0 & 0.0 & 0.3 & 0.0 & 0.3 & 0.3 \\
\hline Ireland & 0.0 & 0.1 & 0.0 & 0.0 & 0.0 & 0.0 & 0.0 & 0.0 & 0.0 & 0.0 & 0.1 & 0.2 \\
\hline
\end{tabular}

Table 3. Origin commercial areas of the companies

\begin{tabular}{|c|c|c|c|c|c|c|c|c|c|c|c|c|}
\hline \multirow{2}{*}{ Origin commercial area } & \multicolumn{10}{|c|}{ Year of publication } & \multirow{2}{*}{ Total } & \multirow{2}{*}{$\%$} \\
\hline & 2017 & 2016 & 2015 & 2014 & 2013 & 2012 & 2011 & 2010 & 2009 & 2008 & & \\
\hline Asia & 4.1 & 4.1 & 2.2 & 2.3 & 4.0 & 1.0 & 2.0 & 4.8 & 4.0 & 3.7 & 32.1 & 42.1 \\
\hline Not specified & 2.0 & 6.3 & 6.0 & 0.0 & 2.0 & 0.0 & 0.0 & 0.3 & 1.0 & 1.5 & 19.0 & 24.9 \\
\hline Middle East & 1.0 & 0.0 & 1.0 & 1.3 & 1.0 & 0.0 & 1.0 & 1.0 & 2.0 & 2.5 & 10.8 & 14.2 \\
\hline Europe & 0.6 & 3.0 & 0.6 & 1.5 & 0.0 & 0.0 & 0.0 & 1.0 & 0.8 & 1.5 & 8.9 & 11.6 \\
\hline North America & 0.2 & 0.5 & 0.2 & 0.5 & 0.0 & 0.0 & 0.0 & 0.3 & 0.3 & 1.7 & 3.6 & 4.7 \\
\hline Africa & 0.0 & 1.0 & 0.0 & 0.3 & 0.0 & 0.0 & 0.0 & 0.0 & 0.0 & 0.0 & 1.3 & 1.7 \\
\hline Australia and New Zealand & 0.1 & 0.2 & 0.0 & 0.0 & 0.0 & 0.0 & 0.0 & 0.0 & 0.0 & 0.2 & 0.5 & 0.7 \\
\hline Latin America & 0.0 & 0.0 & 0.0 & 0.0 & 0.0 & 0.0 & 0.0 & 0.0 & 0.0 & 0.0 & 0.0 & 0.0 \\
\hline
\end{tabular}


world, surpassing its French competitors in 2006, who had occupied the first position in the international construction market together with American companies (Chen \& Orr, 2009). Because of this, 49 Chinese contractors were included in the list of the 225 best international contractors of the ENR in 2007 (Zhao et al., 2009). Also, according to a survey conducted by Korkmaz and Messner (2008), Chinese and South Korean construction companies were identified as the most important competitors in international markets, strengthened by their government support and their labor advantages, as well as low cost and good quality.

Since the main objective of these papers is to analyze the performance variables that influence international success rather than focusing on the destination area, most of the articles do not specify the host country and only some include the commercial area that a company accesses. Table 4 was created using the same criteria followed in Tables 2 and 3 and shows the host commercial area of the companies and the number of papers per year that include it. The host commercial area most often cited in the papers is Asia (18.7\%), followed by Europe (11.0\%), the Middle East (10.1\%), Africa (7.3\%), and North America (5.7\%). These results are in accordance with the conclusions of $\mathrm{Lu}$ et al. (2009), who concluded that, although Chinese companies can compete in markets such as the United States or Europe, about 70\% of their turnover still comes from Asia and Africa. In Asian developing countries, Chinese contractors have the advantage of lower transport costs due to their greater geographical proximity than Western contractors. Furthermore, in other developing Asian countries, closer, bilateral trade links have promoted international activity (Zhao et al., 2009). On the other hand, Korkmaz and Messner (2008) established that income generated by US companies in Europe, the Middle East, and Africa had increased over time, while they had decreased in Latin America, Canada, and Asia.

\section{Qualitative analysis on competitive advantages}

A qualitative analysis of the 76 papers was conducted to achieve the first (G1) and the second (G2) goals, which aim to identify the competitive advantages and the external barriers that companies consider important to achieve international success. These variables have been then grouped into categories by affinity criteria (Carnevalli \& Miguel, 2008).

Forty four competitive advantages that determine the success of the internationalization of companies were detected in the seventy-six papers analyzed. Table 5 shows the competitive advantages and the number of papers that include them. Experienced and trained human resources (25 papers), communication and trust with the client (19 papers), effective communication and trust among stakeholders (18 papers), technology (18 papers), and cultural intelligence (18 papers) are the competitive advantages that are included in a greater number of papers. Moreover, competitive advantages have been grouped into eight categories based on affinity criteria (Carnevalli \& Miguel, 2008): experience of the company, competence of the project team, competence and managerial ability, strategic and organizational adjustment, project management capacity, financial capacity, partnering, and ability to adapt to the destination country.

\subsection{Experience of the company}

The main competitive advantage in this group is a strong reputation, national or international, which can benefit companies in the construction sector (Jewell, 2010). According to Abdul-Aziz et al. (2013), the age of the companies encourages their expansion abroad due to the availability of extensive business contacts, and the availability of a client portfolio or an ISO certification will favor overseas projects contracts. Finally, previous experience in the same type of contracts (Gunhan \& Arditi, 2005; Yildiz et al., 2014) or international experience both influence international success. Companies with international experience reduce the uncertainty generated by work abroad (Barkema et al., 1996) because they adapt better to different environments and have greater knowledge of international rules and regulations in the different host countries (Chen et al., 2016).

\subsection{Competence of the project team}

Competence of the project team (Abdul-Aziz et al., 2013), qualified resources, and commitment to the objectives are considered competitive advantages that influence the success of a company (Khang \& Moe, 2008; Alashwal et al., 2017).

Table 4. Host commercial area of the companies

\begin{tabular}{|c|c|c|c|c|c|c|c|c|c|c|c|c|}
\hline \multirow{2}{*}{ Host commercial area } & \multicolumn{10}{|c|}{ Year of publication } & \multirow{2}{*}{ Total } & \multirow{2}{*}{$\%$} \\
\hline & 2017 & 2016 & 2015 & 2014 & 2013 & 2012 & 2011 & 2010 & 2009 & 2008 & & \\
\hline Not specified & 4.0 & 7.0 & 5.0 & 1.0 & 4.0 & 1.0 & 2.0 & 6.0 & 1.0 & 2.0 & 33.0 & 43.4 \\
\hline Asia & 1.3 & 2.3 & 0.6 & 1.7 & 1.0 & 0.0 & 0.3 & 1.0 & 1.0 & 5.1 & 14.2 & 18.7 \\
\hline Europe & 0.5 & 2.3 & 1.4 & 1.3 & 0.0 & 0.0 & 0.0 & 0.0 & 1.1 & 1.7 & 8.4 & 11.0 \\
\hline Middle East & 0.4 & 2.0 & 0.5 & 1.3 & 1.5 & 0.0 & 0.3 & 0.0 & 0.9 & 0.8 & 7.7 & 10.1 \\
\hline Africa & 0.4 & 1.0 & 1.2 & 0.7 & 0.4 & 0.0 & 0.3 & 0.0 & 1.0 & 0.5 & 5.6 & 7.3 \\
\hline North America & 0.0 & 0.1 & 0.6 & 0.0 & 0.1 & 0.0 & 0.0 & 0.0 & 3.0 & 0.5 & 4.3 & 5.7 \\
\hline Australia and New Zealand & 1.2 & 0.4 & 0.1 & 0.0 & 0.0 & 0.0 & 0.0 & 0.0 & 0.0 & 0.0 & 1.6 & 2.1 \\
\hline Latin America & 0.2 & 0.0 & 0.6 & 0.0 & 0.0 & 0.0 & 0.0 & 0.0 & 0.0 & 0.4 & 1.2 & 1.6 \\
\hline
\end{tabular}


Table 5. Competitive advantages: categories, variables and number of papers

\begin{tabular}{|c|c|c|}
\hline Category & Variable & $\begin{array}{l}\text { Number } \\
\text { of papers }\end{array}$ \\
\hline \multirow{7}{*}{$\begin{array}{l}\text { Experience } \\
\text { of the } \\
\text { company }\end{array}$} & National reputation & 14 \\
\hline & International reputation & 14 \\
\hline & International experience & 8 \\
\hline & Experience in a type of contract & 3 \\
\hline & Hold a quality certification & 2 \\
\hline & Age of the company & 1 \\
\hline & Availability of client portfolio & 1 \\
\hline \multirow{6}{*}{$\begin{array}{l}\text { Competence } \\
\text { of the project } \\
\text { team }\end{array}$} & $\begin{array}{l}\text { Experienced and trained human } \\
\text { resources }\end{array}$ & 25 \\
\hline & Commitment and teamwork & 16 \\
\hline & Appropriate resolution of conflicts & 15 \\
\hline & Technical competence & 11 \\
\hline & Language skills & 5 \\
\hline & International mobility & 1 \\
\hline \multirow{4}{*}{$\begin{array}{l}\text { Competence } \\
\text { and } \\
\text { managerial } \\
\text { ability }\end{array}$} & $\begin{array}{l}\text { Experience and motivation of the } \\
\text { manager }\end{array}$ & 13 \\
\hline & Maintain key human resources & 4 \\
\hline & Motivate human resources & 3 \\
\hline & $\begin{array}{l}\text { Previous business contacts of the } \\
\text { manager }\end{array}$ & 3 \\
\hline \multirow{13}{*}{$\begin{array}{l}\text { Strategic and } \\
\text { organiza- } \\
\text { tional adjust- } \\
\text { ment }\end{array}$} & Technology & 18 \\
\hline & Cost reduction & 16 \\
\hline & $\begin{array}{l}\text { Research Innovation and } \\
\text { Development }\end{array}$ & 12 \\
\hline & Provide quality services & 7 \\
\hline & Organizational capacity & 7 \\
\hline & Provide integrated services & 5 \\
\hline & $\begin{array}{l}\text { Provide services with the best } \\
\text { value for money }\end{array}$ & 4 \\
\hline & Availability of resources & 4 \\
\hline & Learning ability & 3 \\
\hline & Avoid bribery & 3 \\
\hline & Provide specialized services & 2 \\
\hline & Corporate social responsibility & 2 \\
\hline & Avoid inertia & 1 \\
\hline \multirow{3}{*}{$\begin{array}{l}\text { Project } \\
\text { management } \\
\text { capacity }\end{array}$} & Management at different levels & 13 \\
\hline & $\begin{array}{l}\begin{array}{l}\text { Identification and mitigation of } \\
\text { risks }\end{array} \\
\end{array}$ & 11 \\
\hline & Knowledge management & 4 \\
\hline \multirow{2}{*}{$\begin{array}{l}\text { Financial } \\
\text { capacity }\end{array}$} & Own financial capacity & 17 \\
\hline & External financing & 5 \\
\hline \multirow{5}{*}{ Partnering } & $\begin{array}{l}\text { Communication and trust with } \\
\text { the client }\end{array}$ & 19 \\
\hline & $\begin{array}{l}\text { Effective communication and trust } \\
\text { among stakeholders }\end{array}$ & 18 \\
\hline & Trust and commitment of partners & 17 \\
\hline & $\begin{array}{l}\text { Proper choice of suppliers and } \\
\text { subcontractors }\end{array}$ & 7 \\
\hline & Proper choice of partners & 6 \\
\hline
\end{tabular}

End of Table 5

\begin{tabular}{|c|c|c|}
\hline Category & Variable & $\begin{array}{l}\text { Number } \\
\text { of papers }\end{array}$ \\
\hline \multirow{4}{*}{$\begin{array}{l}\text { Ability to } \\
\text { adapt to the } \\
\text { destination } \\
\text { country }\end{array}$} & Cultural intelligence & 18 \\
\hline & $\begin{array}{l}\text { Local knowledge of the host } \\
\text { country }\end{array}$ & 10 \\
\hline & $\begin{array}{l}\text { Ability to adapt to the } \\
\text { environment }\end{array}$ & 9 \\
\hline & Previous knowledge of the client & 3 \\
\hline
\end{tabular}

Performance in previous projects and technical experience are the criteria most valued by clients when seeking a contractor (Watt et al., 2010). In addition, in the selection processes companies must also consider language skills of professionals or provide language training to create a trusting environment that favors the exchange of knowledge (Kivrak et al., 2014), and human resources must be able to move and work in different geographical locations (Winch, 2008). Finally, an appropriate resolution of conflicts has a clear influence on the results of the project (Alashwal et al., 2017).

\subsection{Competence and managerial ability}

Another category is related to managerial conditions, understood as the leadership, design, monitoring, and coordination of the project's stakeholders (Ika \& Donnelly, 2017). Luu et al. (2008) argued that the inability of some companies to hire and retain qualified technical resources causes a decline in their technical performance (Ercan \& Koksal, 2016). Motivation and training provided to human resources to work in diverse environments stands out in China (Winch, 2008). To achieve international success, contractors must consider variables such as the motivation and experience of the manager (Khang \& Moe, 2008); in the same way, Rutihinda (2008) underlined the influence of previous work and learning experiences of the managers in their orientation towards internationalization. Finally, commercial contacts of the managers made in previous jobs will enable them to obtain new contracts (Abdul-Aziz et al., 2013).

\subsection{Strategic and organizational adjustment}

Strategic and organizational adjustment is the capacity of companies to organize themselves and reach the established objectives (Salaman \& Asch, 2003), which creates value for the stakeholders and gives them a competitive advantage (DeSarbo et al., 2005). Organizational capacity is related to obtaining scarce and valuable resources from the external environment, their transformation, and continuous learning and innovation to improve organizational competitiveness (Chew et al., 2008). Learning develops new processes, innovations, and technologies that reduce costs and increase efficiency, providing value to the client and increasing financial results (Kaplan \& Norton, 2007). In the same way, research and development $(\mathrm{R} \& \mathrm{D})$ investments play an important role in the market 
expansion of a company (Ercan \& Koksal, 2016). Watt et al. (2010) established that cost is a key performance indicator for projects, and it is included in benchmarking exercises aimed at identifying best practices (Zafar et al., 2012). Moreover, price and quality are among the most important competitive parameters that regulate the success and long-term prospects of construction companies (Marinič \& Záthurecký, 2014). From the point of view of the value perceived by the client, a competitive advantage can be defined as the price-quality ratio (Lambert, 1980). In addition, offer of specialized services is a strength of the companies facing international activity (Gunhan \& Arditi, 2005); in other cases, there are international clients who prefer to award contracts to companies who can provide integrated services (consultancy, design service, and construction) (Zhao \& Shen, 2008). Corporate social responsibility enhances the competitiveness of a company by hiring better human resources and also improves morale, loyalty, commitment, and productivity (Wu et al., 2015). The lack of ethical and commercial integrity of the contractors can lead to a decline in their performance ( $\mathrm{Fa}$ ridi \& El-Sayegh, 2006), as has happened to companies in some developing countries where bribes are common (Zhao et al., 2009). Finally, inertia in a construction company can lead it to a late internationalization (Abdul-Aziz et al., 2013), impinging its international performance.

\subsection{Project management capacity}

Yalegama et al. (2016) established that project management constitutes a success category, since it increases the competitiveness of contractors (Ngowi et al., 2005). Other studies consider initiation, planning, risk management, and effective control of the projects to be additional success factors (Belassi \& Tukel, 1996; Ahmed \& Azmi bin Mohamad, 2016). Risk management has become critical to the success of international construction projects (Ozorhon et al., 2010; Yildiz et al., 2014). Another factor in the success of international activity is the management of knowledge through the experiences and lessons learned from the human resources (Lu et al., 2013).

\subsection{Financial capacity}

Alashwal et al. (2017) and Abdul-Aziz et al. (2013) emphasized the role of a strong financial capacity of contractors to achieve success in international projects. Another option is the provision of external financing, such as in the case of the Chinese government, which promoted the international activity of Chinese contractors through the establishment of secure financing mechanisms (Zhao et al., 2009). The ability to secure large loans at low interest from financial institutions to finance international projects has become key in international construction (Gunhan \& Arditi, 2005).

\subsection{Partnering}

In the last two decades, partnering in the construction industry has grown in importance and project participants have adopted a win-win philosophy to maximize the effectiveness of the resources of each organization (Hong et al., 2011). In successful international projects, it is vital to maintain an effective engagement between stakeholders (Office of Government Commerce, 2009) as well as the linking of contractors to obtain resources and transfer them properly (Du et al., 2016). Specifically, building trust with the client can help contractors obtain long-term benefits and more business opportunities to expand their market share (Du et al., 2016). The quality of the relationship with the client influences achievement of success (Ozorhon et al., 2010). In the same way, the activity of an IJV is influenced by the nature of the relations between partners (Parkhe, 1991), highlighting the degree of trust as one of the most important factors in the knowledge exchange and in the success of the partnership (Mohr \& Puck, 2005). Another critical success factor in collaborative projects is an adequate selection of partners (Akgul et al., 2017). Moreover, the complexity of international activity justifies the importance of properly choosing suppliers and subcontractors and managing relationships with them for the success of projects (Abdelghany \& Ezeldin, 2010).

\subsection{Ability to adapt to the destination country}

The ability of the team to establish links with local entities in the host country is essential for successful international activity (Abdelghany \& Ezeldin, 2010). Projects do not develop separated from their external environment, so contractors implement location strategies to improve their performance (Jung et al., 2012). Therefore, adapting knowledge to the local market and integrating the knowledge of the organization into the company are competitive requirements for multinational organizations (Javernick-Will, 2013). To achieve success in the global market, companies must adjust to the environmental conditions of the destination countries (Yitmen, 2013). In the same way, the ability to adapt to the host country is based on the cultural intelligence of the project team (Welch et al., 2001), which is considered one of the main competitive advantages to increase the performance of the contractors (Yitmen, 2013).

\section{Qualitative analysis on external barriers}

Twenty seven external barriers that affect the international performance of the contractors have been identified in the seventy six papers analyzed, fulfilling Research Goal G2. These variables have been grouped into seven categories according to affinity criteria (Carnevalli \& Miguel, 2008): market in the host country, links between the origin country and the host country, political environment, economic environment, socio-cultural environment, legal environment, and availability of resources. Table 6 shows the categories, external barriers and the number of papers in which each external barrier is included. Results indicate that cultural differences (22 papers) and political risks (21 papers) of the host country stand out over the other barriers. 
Table 6. External barriers: categories, variables and number of papers

\begin{tabular}{|c|c|c|}
\hline Category & Variable & $\begin{array}{l}\text { Number } \\
\text { of papers }\end{array}$ \\
\hline \multirow{5}{*}{$\begin{array}{l}\text { Market in the } \\
\text { host country }\end{array}$} & Local competition & 11 \\
\hline & Foreign competition & 11 \\
\hline & Market size & 6 \\
\hline & Market growth & 3 \\
\hline & Level of agglomeration & 2 \\
\hline \multirow{3}{*}{$\begin{array}{l}\text { Links between } \\
\text { origin country } \\
\text { and host } \\
\text { country }\end{array}$} & Commercial links & 9 \\
\hline & Geographical distance & 7 \\
\hline & Air connection & 2 \\
\hline \multirow{4}{*}{$\begin{array}{l}\text { Political } \\
\text { environment }\end{array}$} & Political risk & 21 \\
\hline & Corruption & 7 \\
\hline & Citizen insecurity & 6 \\
\hline & Local protectionism & 2 \\
\hline \multirow{5}{*}{$\begin{array}{l}\text { Economic } \\
\text { environment }\end{array}$} & Economic stability & 11 \\
\hline & Financial risk & 9 \\
\hline & Currency fluctuations & 7 \\
\hline & Payment delays & 5 \\
\hline & Capital requirement & 2 \\
\hline \multirow{5}{*}{$\begin{array}{l}\text { Socio-cultural } \\
\text { environment }\end{array}$} & Cultural differences & 22 \\
\hline & Language differences & 8 \\
\hline & Social risk & 4 \\
\hline & Religious beliefs & 2 \\
\hline & Interest in the project & 2 \\
\hline \multirow{2}{*}{$\begin{array}{l}\text { Legal } \\
\text { environment }\end{array}$} & Institutional differences & 10 \\
\hline & Legal risk & 4 \\
\hline \multirow{3}{*}{$\begin{array}{l}\text { Availability of } \\
\text { resources }\end{array}$} & Lack of availability of resources & 6 \\
\hline & Local labor conditions & 3 \\
\hline & Existence of infrastructures & 2 \\
\hline
\end{tabular}

\subsection{Market in the host country}

The selection of markets is critical for companies that make the decision to internationalize (Papadopoulos \& Martín Martín, 2011) because markets have a long-term impact on the overall success of these companies. Contractors prefer to enter countries where the market is larger (Brewer, 2001) because of the higher income and greater prospects for long-term stability (Chen et al., 2016). Likewise, market growth in host countries can attract foreign businesses (Kirsch et al., 2002). However, markets with excessive competition can negatively affect international business (Zhao et al., 2016), and they will be less attractive for foreign companies (Sullivan \& Bauerschmidt, 1990). Finally, the economy of the industrial organization assumes that the level of agglomeration in an industry increases competition, so that profitability and business sales will decrease (Scherer \& Ross, 1990).

\subsection{Links between origin country and host country}

The success of the entry strategy depends on the nature of the links between the government of the origin country of the company and the government of the host country (Konijn \& van Tulder, 2015). Business in a geographically distant country is generally complex; the exchange of information is easier and more frequent between nearby countries, while transport costs for raw materials and products can be excessive between remote countries (Ghemawat, 2004). Moreover, Bannò and Redondi (2014) established that air connectivity increases investment in a specific area, and Abdul-Aziz et al. (2013) reported that trade agreements provide companies with greater knowledge of the destination countries.

\subsection{Political environment}

In their international activity, contractors strive to mitigate exposure to political risk in order to survive and achieve success (Deng \& Low, 2014). Political stability is considered by contractors to be a guarantee of payment for their work; therefore, it is a crucial variable in the decision to enter and become established in a country (Erramilli et al., 1997). This aspect is closely related to the existence of corruption in a country, which is common in many African countries, as corruption can make obtaining contracts difficult (Diawara, 1998). Performance in international projects can also be affected by regional factors, such as a hostile environment or terrorism (Lei et al., 2017), being the weak rule of law and governance another reason why companies do not enter the country (AbdulAziz et al., 2013). Finally, the choice to enter a country will be negatively affected by unfavorable government attitudes toward foreign companies (Deng \& Low, 2014) or by excessive protectionism for local companies (Jewell, 2010).

\subsection{Economic environment}

The economic conditions in a country can be considered entry barriers for foreign companies and affect project delivery (Lei et al., 2017). According to Abdul-Aziz et al. (2013), two of the most significant economic location factors considered by companies are financial risk and capital requirement. Financial risk is one of the main factors in entry market decisions due to the high initial investment required (Monroy Antón et al., 2011). On the other hand, delays in the payment for work in Malaysia have had a negative impact on the financial performance of smallscale contractors, causing delays in projects, abandonment, and replacement of the material specified by others with lower quality products (Sambasivan \& Soon, 2007). Similarly, Chinese contractors, who usually work in developing countries lacking funds, are exposed to client defaults (Zhao et al., 2009) and exchange rates that often fluctuate significantly. The high volatility of the exchange rate of local currency constitutes an economic risk factor that will affect the profitability of a project (Jang et al., 2015). Ling and Hoi (2006) conclude that many of Sin- 
gapore's construction companies do not obtain profitable investments because they assume the risk of fluctuation when entering the Indian market (Duvholt et al., 2016).

\subsection{Socio-cultural environment}

"Social risk" is a term used by Booz Allen Hamilton to refer to the challenges that companies face due to the social consequences of their commercial activity (Kytle \& Ruggie, 2005). Likewise, Alashwal et al. (2017) emphasize the importance of the social environment of the project to achieve success in international activity. Moreover, cultural or religious differences can affect the performance of international projects (Lei et al., 2017); in the case of joint ventures, cultural differences between project teams can originate conflicts, misunderstandings, and a poor performance of the project (Ajmal, 2015). According to Öz (2001), contractors who can quickly adapt to the local culture of the host market are more likely to succeed. Similarly, Carpintero (2011) stresses the importance of language differences when contractors enter new markets. Finally, variables such as interest and public acceptance of the project should be considered and controlled periodically (Xiaopeng \& Pheng, 2013).

\subsection{Legal environment}

Contractors who enter a country for the first time must know its laws and regulations (Han et al., 2007) because an inadequate legal system influences the profitability of the projects (Jang et al., 2015). According to institutional theory, organizations must adjust to institutional systems for their survival (Meyer \& Rowan, 1977). Specifically, institutional differences are a challenge for Chinese international contractors and a factor that negatively influences their entry market decision (Chen et al., 2006); differences in technical standards can become barriers for their international business and cause overruns (Chua et al., 2003).

\subsection{Availability of resources}

Another barrier that international contractors face when they access a country is the lack of availability of local resources - supplies of local labor and conditions for procurement, production, and supply of materials (Alashwal et al., 2017; Jang et al., 2015). Khang and Moe (2008) consider the provision of adequate local capacity as a factor that affects the success of international projects. Contractors also have to consider the existence and state of infrastructures in the host country, and the local labor characteristics and welfare conditions, because they will have an impact on project performance (Jang et al., 2015).

\section{Dependency relationship between variables}

The second phase of the analysis aims to find out if there are relationships between the competitive advantages that most influence the international success of the companies and their origin country (G3) and determine if relationships exist between the main external barriers that com- panies must face abroad and the host countries they access (G4). The SPSS statistical program, version 24, was used, and the Chi-Square $\left(\chi^{2}\right)$ test was carried out as the statistical method to analyze these relationships.

\subsection{Relationship between competitive advantages and origin countries (G3)}

Based on the literature review, the Chi-Square $\left(\chi^{2}\right)$ test was developed to analyze the relationship between competitive advantages and the origin commercial areas as well as between competitive advantages and the origin countries most cited in the papers reviewed: China, USA, Japan, Turkey and South Korea. In this case, the null hypothesis (H0) establishes the independence between both variables, being satisfied when $\mathrm{p}>0.05$. The results obtained imply that there is no significant relationship between the origin commercial area and the competitive advantages, but there is a relationship between the origin country and the competitive advantage related to competence and managerial ability. Table 7 shows that $\chi^{2}=12.682$ and $\mathrm{p}=0.027$ in this case; as such, null hypothesis (H0) is rejected, and the G3 goal is defined - there is a significant relationship between the origin country of a company and the competitive advantage "competence and managerial ability". To determine the degree of association of the categorical variables with more than two dimensions, it is necessary to calculate the ratio $\mathrm{CC} / \mathrm{CCmax}$. A strong dependence occurs when $\mathrm{CC} / \mathrm{CCmax} \geq 0.7$; moderate dependence when $0.5 \leq \mathrm{CC} / \mathrm{CCmax}<0.7$, and low dependence when $\mathrm{CC} /$ CCmax $<0.5$ (Field, 2013). The value obtained is CC/CC$\max =0.435$; therefore, there is a low dependence between the origin country of a company and its competence and managerial ability, although this value is close to 0.5 (the limit for a moderate dependence).

These results are supported by the literature review. Chinese international construction companies generally lack trained professionals, particularly in management areas (project, risk, finance) and international law; therefore, although some project managers have achieved success in the regional market, it is important that Chinese construction companies develop management skills abroad, such as the organization of the work or stakeholder management (Lu et al., 2013). Similarly, according to Korkmaz and Messner (2008), the management capacity of the project managers is perceived to be one of the most important competitive advantages of Turkish construction companies in international markets.

Table 7. Chi-Square test between competence and managerial ability and origin country

\begin{tabular}{|l|c|}
\hline Competence and managerial ability-origin country & Value \\
\hline$\left(\chi^{2}\right)$ & 12.682 \\
\hline Sig. $(p)$ & 0.027 \\
\hline Contingency coefficient (CC) & 0.355 \\
\hline CC/CCmax & 0.435 \\
\hline
\end{tabular}

Note: $\left(\chi^{2}\right)$ : Chi-square value; Sig.: p-value; CC: Contingency coefficient; CCmax $=0.816$. 


\subsection{Relationship between external barriers and host markets (G4)}

The Chi-Square $\left(\chi^{2}\right)$ test was carried out, establishing as null hypothesis ( $\mathrm{H} 0)$ the independence between external barriers and destination countries, which is verified when $p>0.05$. Table 8 shows a level of significance lower than 0.05 for the barriers "political environment", "economic environment", and "link between countries", such that the null hypothesis is rejected and the G4 goal is determined; there is a significant relationship between the destination country and the barriers previously mentioned. The degree of association defined by the ratio $\mathrm{CC} / \mathrm{Cmax}$ indicates that there is a moderate dependence between political environment and the host country and low dependences between economic environment or link between countries and the destination countries.

These results are supported by previous contributions. Kim et al. (2013) established that international contractors depend on the host country for income because they have to open local offices, obtain licences, establish relationships with local contractors and suppliers, and tender for projects financed by the government or by international investment banks. Likewise, Fang et al. (2004) identified "difficulties in the capital return" and "delayed payments by the owners" as the main economic risk factors in the Chinese construction market. The economic risk related to the currency fluctuation in a specific country is a large risk factor, although many contractors think that it is a good opportunity to obtain benefits (Duvholt et al., 2016).

Regarding political risks, they are high in developing countries (Zhao \& Shen, 2008). According to Chen and Orr (2009), the greatest threat to investment in Africa is the political instability, and Diawara (1998) established that contractors prefer to enter other areas because of the corruption that strangles the African market. In addition, Wang et al. (1999) analyzed the political risks in the Chinese market, such as Chinese government restrictions, that create significant obstacles to foreign contractors. For Turkish contractors, the country's political stability is rated as one of the main factors in obtaining contracts in a new market (Korkmaz \& Messner, 2008).

Finally, commercial links between the origin country and the destination country lead to successful entry modes (Chen, 2008). The Chinese government considers export of services to be as important as to attract foreign investment; therefore, it has developed multilateral cooperation with foreign countries to help international Chinese contractors to obtain contracts (Zhao \& Shen, 2008).
Sino-African political relations are solid and favor trade business of mutual benefit (Chen \& Orr, 2009). In contrast to these studies, Ozorhon et al. (2010) established that host country conditions, such as political risk, macroeconomic conditions, legal system, and host government relations with foreign entities, do not significantly affect the performance of IJVs because they have sufficient resources and skills, work in a cooperative organization, and are able to solve risks with success.

\section{Conclusions}

\section{Contributions}

A total of 76 articles related to performance in the international construction market in the period of 2008-2017 have been analyzed, using the bibliometric analysis as the main research method. Considering the number of articles published in the study period, it should be noted that the largest number of publications related to the international success of construction took place in 2016, while the interest in this research area was significantly reduced in the 2011-2014 period, as established by another research.

Regarding the origin country of the contractors, China is the country most included in papers while Asia is the commercial area of destination that most often appears in the articles, confirming the fact that the Chinese construction market is one of the largest markets in the world. The results show that Asia, Europe, and the Middle East are the host commercial areas most cited in the papers. According to several studies Asia and Africa are the commercial areas preferred by Chinese contractors and Asia, Europe and the Middle East are the main host areas for US contractors.

In relation to the competitive advantages identified, the availability of experienced and trained human resources is the advantage most cited in the papers and is one of the criteria most valued by clients when selecting a contractor. Communication and trust with both the client and among stakeholders, in decreasing order, are the following outstanding advantages, showing the importance of maintaining good relations with the client to obtain longterm benefits and highlighting the value of effective engagement between stakeholders. Finally, results highlight technology, since it reduces costs and increases efficiency, and the cultural intelligence of the project team, as one of the main competitive advantages to obtain success.

Among the main barriers, cultural differences and political stability are mentioned in a greater number of

Table 8. Chi-Square test between external barriers and host country

\begin{tabular}{|l|c|c|c|c|}
\hline \multicolumn{1}{|c|}{ Barriers } & $\left(\chi^{2}\right)$ & Sig. $(p)$ & Contingency coefficient $(C C)$ & CC/CCmax \\
\hline Political environment & 35.910 & 0.000 & 0.461 & 0.564 \\
\hline Economic environment & 15.488 & 0.031 & 0.323 & 0.395 \\
\hline Link between countries & 19.332 & 0.007 & 0.356 & 0.436 \\
\hline
\end{tabular}

Note: $\left(\chi^{2}\right)$ : Chi-square value; Sig.: $\mathrm{p}$-value; CC: Contingency coefficient; CCmax $=0.816$. 
publications, stating that these factors are vital in access to a country and to improve performance.

Finally, the Chi-Square $\left(\chi^{2}\right)$ test shows that there is a dependency relationship between the origin country of a company and the competitive advantage "competence and managerial ability", and that the barriers "economic environment", "political environment", and "link between countries" are also related to the target market where a company accesses, confirming the importance of considering the characteristics of the origin and host country of a company in its internationalization.

\section{Limitations}

Data considered in this research come from articles related to the international success of companies in the construction sector in the period from 2008-2017 without considering the country of origin, commercial area of destination, or the competitive advantages and external barriers that have more influence in the international success in previous years or in other sectors. Likewise, to detect the main competitive advantages and barriers that influence the international success of construction companies, this study is limited to defining those that include the 76 articles analyzed without taking into account companies from the construction sector with international activity from other countries or that are directed to other destination markets not included in the sample of articles of the present research. Regarding the main barriers identified, this paper is not intended to benchmark one region against others. This would require a broader study of international trade in each region as well as analysis of the success of each company that accesses them. The conclusions of this study are limited to the data obtained from the selected sample of articles in the study period.

\section{Recommendations}

The uncertainty associated with the international construction market forces companies to acquire a detailed knowledge of the variables that influence international success. Although companies carry out market studies and internal analyses when undertaking activity in a certain foreign country, the randomness associated with internationalization due to the multitude of variables that influence the process makes it necessary to perform a greater number of studies that seek to find out the most influential variables in international performance. Thus, the present study aims to raise awareness of the most influential competitive advantages and external barriers that help contractors achieve international success. Moreover, the relationship between some of these variables is observed depending on the host country of the companies or the destination market. Before becoming international, it is important that companies carry out internal analyses to evaluate the disposition of these advantages as well as external analyses to identify the main barriers they face according to the market they access.

\section{Future lines of research}

The findings of this research consider the opinion of the companies surveyed in the publications as well as the findings of the research related to international success carried out during the designated time frame. Future research could address the main competitive advantages and external barriers that influence the international success of the construction companies in a more detailed way, studying the case of several companies with different origin countries and with diverse commercial area of destination. These studies would allow for obtaining more data in order to deepen the relationships between these variables (competitive advantages and external barriers) with the origin countries and destination areas of the companies.

\section{Funding}

This research received no external funding.

\section{Author contributions}

A. L-T conceived the study and was responsible for the design and development of the literature review, investigation and resources, data analysis and partial writing. T. G-S was responsible of methodology and conceptualization. L. M-D was responsible of the data curation and partial writing. EP was responsible for partial writing, reviewing, editing and supervision. All the authors have read and approved the final manuscript.

\section{Disclosure statement}

Authors do not have any competing financial, professional, or personal interests from other parties.

\section{References}

Abdelghany, Y., \& Ezeldin, A. S. (2010, May). Classification of risks for international construction joint ventures (ICJV) projects. In Construction Research Congress 2010. Banff, Alberta, Canada. https://doi.org/10.1061/41109(373)126

Abdul-Aziz, A.-R., Nor Azmi, H.-A. C. M., Law, Y.-H., \& Pengiran, D. N. (2013). Internationalization of construction-related consultants: Impact of age and size. Journal of Professional Issues in Engineering Education and Practice, 139(2), 148-155. https://doi.org/10.1061/(ASCE)EI.1943-5541.0000135

Ahmed, R., \& Azmi bin Mohamad, N. (2016). Exploring the relationship between multi-dimensional top management support and project success: an international study. Engineering Management Journal, 28(1), 54-67.

https://doi.org/10.1080/10429247.2015.1136525

Ajmal, M. M. (2015). Cultural effects on trust building in international projects' stakeholders. International Journal of Information Technology Project Management, 6(3), 41-57. https://doi.org/10.4018/IJITPM.2015070103

Akgul, B. K., Ozorhon, B., Dikmen, I., \& Birgonul, M. T. (2017). Social network analysis of construction companies operating in international markets: Case of Turkish contractors. Journal of Civil Engineering and Management, 23(3), 327-337. https://doi.org/10.3846/13923730.2015.1073617 
Alashwal, A. M., Fareed, N. F., \& Al-obaidi, K. M. (2017). Determining success criteria and success factors for international construction projects for Malaysian contractors. Construction Economics and Building, 17(2), 62-80. https://doi.org/10.5130/AJCEB.v17i2.5319

Awil, A. U., \& Abdul-Aziz, A. R. (2005, July). The role of government in the internationalization of Malaysian housing developers. In Queensland University of Technology Research Week International Conference (pp. 4-8), Brisbane, Australia.

Bannò, M., \& Redondi, R. (2014). Air connectivity and foreign direct investments: Economic effects of the introduction of new routes. European Transport Research Review, 6(4), 355363. https://doi.org/10.1007/s12544-014-0136-2

Barkema, H. G., Bell, J. H. J., \& Pennings, J. M. (1996). Foreign entry, cultural barriers, and learning. Strategic Management Journal, 17(2), 151-166.

https://doi.org/10.1002/(SICI)1097-0266(199602)17:2<151: :AID-SMJ799>3.0.CO;2-Z

Belassi, W., \& Tukel, O. I. (1996). A new framework for determining critical success/failure factors in projects. International Journal of Project Management, 14(3), 141-151. https://doi.org/10.1016/0263-7863(95)00064-X

Brewer, P. (2001). International market selection: Developing a model from Australian case studies. International Business Review, 10(2), 155-174. https://doi.org/10.1016/S0969-5931(00)00049-4

Bryman, A. (2016). Social research methods. Oxford University Press.

Burnard, P. (1991). A method of analysing interview transcripts in qualitative research. Nurse Education Today, 11(6), 461466. https://doi.org/10.1016/0260-6917(91)90009-Y

Carnevalli, J. A., \& Miguel, P. C. (2008). Review, analysis and classification of the literature on QFD-Types of research, difficulties and benefits. International Journal of Production Economics, 114(2), 737-754.

https://doi.org/10.1016/j.ijpe.2008.03.006

Carpintero, S. (2011). The competitive advantages of the Spanish companies in the international toll road industry. Journal of Civil Engineering and Management, 17(4), 483-493.

https://doi.org/10.3846/13923730.2011.625632

Chen, C. (2008). Entry mode selection for international construction markets: The influence of host country related factors. Construction Management and Economics, 26(3), 303314. https://doi.org/10.1080/01446190701882382

Chen, M. X., Otsuki, T., \& Wilson, J. S. (Eds). (2006). Do standards matter for export success? (Policy research working papers). World Bank Publications.

https://doi.org/10.1596/1813-9450-3809

Chen, C., \& Orr, R. J. (2009). Chinese contractors in Africa: Home government support, coordination mechanisms, and market entry strategies. Journal of Construction Engineering and Management, 135(11), 1201-1210.

https://doi.org/10.1061/(ASCE)CO.1943-7862.0000082

Chen, C., Wang, Q., Martek, I., \& Li, H. (2016). International market selection model for large Chinese contractors. Journal of Construction Engineering and Management, 142(10), 04016044.

https://doi.org/10.1061/(ASCE)CO.1943-7862.0001122

Chew, D. A. S., Yan, S., \& Cheah, C. Y. J. (2008). Core capability and competitive strategy for construction SMEs in China. Chinese Management Studies, 2(3), 203-214. https://doi.org/10.1108/17506140810895898

Chua, D. K. H., Wang, Y., \& Tan, W. T. (2003). Impacts of obstacles in East Asian cross-border construction. Journal of
Construction Engineering and Management, 129(2), 131-141. https://doi.org/10.1061/(ASCE)0733-9364(2003)129:2(131)

Deng, X., \& Low, S. P. (2014). Exploring critical variables that affect political risk level in international construction projects: Case study from Chinese contractors. Journal of Professional Issues in Engineering Education and Practice, 140(1).

https://doi.org/10.1016/j.jtice.2016.03.001

DeSarbo, W. S., Di Benedetto, C. A., Song, M., \& Sinha, I. (2005). Revisiting the miles and snow strategic framework: Uncovering interrelationships between strategic types, capabilities, environmental uncertainty, and firm performance. Strategic Management Journal, 26(1), 47-74.

https://doi.org/10.1002/smj.431

Dey, I. (2003). Qualitative data analysis: A user friendly guide for social scientists. Routledge.

https://doi.org/10.4324/9780203412497

Diawara, M. (1998). Towards a regional imaginary in Africa. Duke University Press.

Diaz-Sarachaga, J. M., Jato-Espino, D., Alsulami, B., \& CastroFresno, D. (2016). Evaluation of existing sustainable infrastructure rating systems for their application in developing countries. Ecological Indicators, 71, 491-502.

https://doi.org/10.1016/j.ecolind.2016.07.033

Diaz-Sarachaga, J. M., Jato-Espino, D., \& Castro-Fresno, D. (2017). Methodology for the development of a new Sustainable Infrastructure Rating System for Developing Countries (SIRSDEC). Environmental Science \& Policy, 69, 65-72. https://doi.org/10.1016/j.envsci.2016.12.010

Downe-Wamboldt, B. (1992). Content analysis: method, applications, and issues. Health Care for Women International, 13(3), 313-321. https://doi.org/10.1080/07399339209516006

Du, L., Tang, W., Liu, C., Wang, S., Wang, T., Shen, W., \& Zhou, Y. (2016). Enhancing engineer-procure-construct project performance by partnering in international markets: Perspective from Chinese construction companies. International Journal of Project Management, 34(1), 30-43.

https://doi.org/10.1016/j.ijproman.2015.09.003

Dunning, J. H. (2000). The eclectic paradigm as an envelope for economic and business theories of MNE activity. International Business Review, 9(2), 163-190. https://doi.org/10.1016/S0969-5931(99)00035-9

Duvholt, J. E., Follinglo, K. A., Lædre, O., \& Lohne, J. (2016). International competition on the Norwegian infrastructure market. Energy Procedia, 96, 855-867. https://doi.org/10.1016/j.egypro.2016.09.147

Engineering News Record (ENR). (2017). The top 250 international contractors.

Ercan, T., \& Koksal, A. (2016). Competitive Strategic Performance Benchmarking (CSPB) model for international construction companies. KSCE Journal of Civil Engineering, 20, 1657-1668. https://doi.org/10.1007/s12205-015-0733-1

Erramilli, M. K., Agarwal, S., \& Kim, S. S. (1997). Are firm-specific advantages location-specific too? Journal of International Business Studies, 28(4), 735-757. https://doi.org/10.1057/palgrave.jibs.8490117

Essl, I., \& Mauerhofer, V. (2018). Opportunities for mutual implementation of nature conservation and climate change policies: A multilevel case study based on local stakeholder perceptions. Journal of Cleaner Production, 183, 898-907. https://doi.org/10.1016/j.jclepro.2018.01.210

Fang, D., Li, M., Fong, P. S. W., \& Shen, L. (2004). Risks in Chinese construction market - Contractors' perspective. Journal of Construction Engineering and Management, 130(6), 853-861. https://doi.org/10.1061/(ASCE)0733-9364(2004)130:6(853) 
Faridi, A. S., \& El-Sayegh, S. M. (2006). Significant factors causing delay in the UAE construction industry. Construction Management and Economics, 24(11), 1167-1176. https://doi.org/10.1080/01446190600827033

Field, A. (2013). Discovering statistics using IBM SPSS statistics. Sage Publicactions.

Ghemawat, P. (2004). Distance still matters: The hard reality of global expansion. Harvard Business Review. https://hbr. org/2001/09/distance-still-matters-the-hard-reality-of-globalexpansion

Gundes, S., \& Aydogan, G. (2016). Bibliometric analysis of research in international construction. Canadian Journal of Civil Engineering, 43(4), 304-311. https://doi.org/10.1139/cjce-2015-0127

Gunhan, S., \& Arditi, D. (2005). Factors affecting international construction. Journal of Construction Engineering and Management, 131(3), 273-282.

https://doi.org/10.1061/(ASCE)0733-9364(2005)131:3(273)

Han, S. H., Park, S. H., Kim, D. Y., Kim, H., \& Kang, Y. W. (2007). Causes of bad profit in overseas construction projects. Journal of Construction Engineering and Management, 133(12), 932-943.

https://doi.org/10.1061/(ASCE)0733-9364(2007)133:12(932)

Hong, Y., Chan, D. W., Chan, A. P., \& Yeung, J. F. (2011). Critical analysis of partnering research trend in construction journals. Journal of Management in Engineering, 28(2), 82-95. https://doi.org/10.1061/(ASCE)ME.1943-5479.0000084

Ika, L. A., \& Donnelly, J. (2017). Success conditions for international development capacity building projects. International Journal of Project Management, 35(6), 1022-1023.

https://doi.org/10.1016/j.ijproman.2016.10.005

Jang, W., Lee, J. K., Lee, J., \& Han, S. H. (2015). Naive Bayesian classifier for selecting good/bad projects during the early stage of international construction bidding decisions. Mathematical Problems in Engineering, 2015, ID 830781.

https://doi.org/10.1155/2015/830781

Javernick-Will, A. (2013). Local embeddedness and knowledge management strategies for project-based multi-national firms. Engineering Management Journal, 25(3), 16-26. https://doi.org/10.1080/10429247.2013.11431979

Jewell, C. A. (2010). Exporting construction professional services in a global service economy. http://citeseerx.ist.psu.edu/viewdoc/download?doi=10.1.1.687.4922\&rep=rep1\&type=pdf

Jung, W., Han, S. H., Park, H., \& Kim, D. Y. (2010). Empirical assessment of internationalization strategies for small and medium construction companies. Journal of Construction Engineering and Management, 136(12), 1306-1316.

https://doi.org/10.1061/(ASCE)CO.1943-7862.0000237

Jung, W., Han, S. H., Koo, B., \& Jang, W. (2012). Which strategies are more effective for international contractors during boom and recession periods? Journal of Management in Engineering, 28(3), 281-290.

https://doi.org/10.1061/(ASCE)ME.1943-5479.0000087

Kaplan, R. S., \& Norton, D. P. (2007). Using the balanced scorecard as a strategic management system. Harvard Business Review. https://hbr.org/2007/07/using-the-balanced-scorecardas-a-strategic-management-system

Khang, D. B., \& Moe, T. L. (2008). Success criteria and factors for international development projects: A life-cycle-based framework. Project Management Journal, 39(1), 72-84. https://doi.org/10.1002/pmj.20034

Kim, D. Y., Ashuri, B., \& Han, S. H. (2013). Financial valuation of investments in international construction markets: Real- options approach for market-entry decisions. Journal of Management in Engineering, 29(4), 355-368.

https://doi.org/10.1061/(ASCE)ME.1943-5479.0000152

Kirsch, R. J., Laird, K. R., \& Evans, T. G. (2002). The entry of international CPA firms into emerging markets: Motivational factors and growth strategies. The International Journal of Accounting, 35(1), 99-119.

https://doi.org/10.1016/S0020-7063(99)00048-5

Kivrak, S., Arslan, G., Tuncan, M., \& Birgonul, M. T. (2014). Impact of national culture on knowledge sharing in international construction projects. Canadian Journal of Civil Engineering, 41(7), 642-649. https://doi.org/10.1139/cjce-2013-0408

Konijn, P., \& van Tulder, R. (2015). Resources-for-infrastructure (R4I) swaps a new model for successful internationalisation strategies of rising power firms? Critical Perspectives on International Business, 11(3/4), 259-284.

https://doi.org/10.1108/cpoib-02-2013-0008

Korkmaz, S., \& Messner, J. I. (2008). Competitive positioning and continuity of construction firms in international markets. Journal of Management in Engineering, 24(4), 207-216. https://doi.org/10.1061/(ASCE)0742-597X(2008)24:4(207)

Kytle, B., \& Ruggie, J. G. (2005). Corporate social responsibility as risk management. A model for multinationals (Working paper No. 10). Harvard University.

Lambert, D. R. (1980). Price as a quality signal: the tip of the iceberg. Economic Inquiry, 18(1), 144-150. https://doi.org/10.1111/j.1465-7295.1980.tb00565.x

Lee, S.-H., Jeon, R.-K., Kim, J.-H., \& Kim, J.-J. (2011). Strategies for developing countries to expand their shares in the global construction market: Phase-based SWOT and AAA analyses of Korea. Journal of Construction Engineering and Management, 137(6), 460-470. https://doi.org/10.1061/(ASCE)CO.1943-7862.0000316

Lee, K.-W., Han, S. H., Park, H., \& David Jeong, H. (2016). Empirical analysis of host-country effects in the international construction market: An industry-level approach. Journal of Construction Engineering and Management, 142(3), 04015092. https://doi.org/10.1061/(ASCE)CO.1943-7862.0001083

Lei, Z., Tang, W., Duffield, C., Zhang, L., \& Hui, F. K. P. (2017). The impact of technical standards on international project performance: Chinese contractors' experience. International Journal of Project Management, 35(8), 1597-1607. https://doi.org/10.1016/j.ijproman.2017.09.002

Ling, F. Y. Y., \& Hoi, L. (2006). Risks faced by Singapore firms when undertaking construction projects in India. International Journal of Project Management, 24(3), 261-270. https://doi.org/10.1016/j.ijproman.2005.11.003

Liu, X., Buck, T., \& Shu, C. (2005). Chinese economic development, the next stage: Outward FDI? International Business Review, 14(1), 97-115. https://doi.org/10.1016/j.ibusrev.2004.12.003

Lu, W., Li, H., Shen, L., \& Huang, T. (2009). Strengths, weaknesses, opportunities, and threats analysis of Chinese construction companies in the global market. Journal of Management in Engineering, 25(4), 166-176.

https://doi.org/10.1061/(ASCE)0742-597X(2009)25:4(166)

Lu, W., Liu, A. M. M., Rowlinson, S., \& Poon, S. W. (2013). Sharpening competitive edge through procurement innovation: Perspectives from Chinese international construction companies. Journal of Construction Engineering and Management, 139(3), 347-351.

https://doi.org/10.1061/(ASCE)CO.1943-7862.0000614

Luu, V. T., Kim, S. Y., \& Huynh, T. A. (2008). Improving project management performance of large contractors using bench- 
marking approach. International Journal of Project Management, 26(7), 758-769.

https://doi.org/10.1016/j.ijproman.2007.10.002

Marinič, P., \& Záthurecký, V. (2014). Evaluation of the construction industry's economic situation and expected development according to managers of SMBs. Central European Journal of Management, 1(1), 49-64.

https://doi.org/10.5817/CEJM2014-1-5

Meyer, J. W., \& Rowan, B. (1977). Institutionalized organizations: Formal structure as myth and ceremony. American Journal of Sociology, 83(2), 340-363. https://doi.org/10.1086/226550

Mizuno, S. (1993). Gerência para melhoria da qualidade: as sete novas ferramentas de controle da qualidade. Rio de Janeiro: LTC.

Mohr, A. T., \& Puck, J. F. (2005). Managing functional diversity to improve the performance of international joint ventures. Long Range Planning, 38(2), 163-182.

https://doi.org/10.1016/j.lrp.2005.02.004

Monroy Antón, A. J., Sáez Rodríguez, G., \& Rodríguez López, Á. (2011). Financial risks in construction projects. African Journal of Business Management, 5(31), 12325-12328.

https://doi.org/10.5897/AJBM11.1463

Mosley, J. C., \& Bubshait, A. A. (2016). Performance evaluation of international contractors in Saudi Arabia. Journal of Professional Issues in Engineering Education and Practice, 142(1), 04015007.

https://doi.org/10.1061/(ASCE)EI.1943-5541.0000254

Ngowi, A. B., Pienaar, E., Talukhaba, A., \& Mbachu, J. (2005). The globalisation of the construction industry - A review. Building and Environment, 40(1), 135-141. https://doi.org/10.1016/j.buildenv.2004.05.008

Office of Government Commerce. (2009). Managing successful projects with PRINCE2. The Stationery Office.

Öz, Ö. (2001). Sources of competitive advantage of Turkish construction companies in international markets. Construction Management and Economics, 19(2), 135-144.

https://doi.org/10.1080/01446190010009988

Ozorhon, B., Arditi, D., Dikmen, I., \& Birgonul, M. T. (2010). Performance of international joint ventures in construction. Journal of Management in Engineering, 26(4), 209-222. https://doi.org/10.1061/(ASCE)ME.1943-5479.0000022

Papadopoulos, N., \& Martín Martín, O. (2011). International market selection and segmentation: Perspectives and challenges. International Marketing Review, 28(2), 132-149. https://doi.org/10.1108/02651331111122632

Park, H., Lee, K.-W., Jeong, H. D., \& Han, S. H. (2014, May). Effect of institutional risks on the performance of international construction projects. In Construction Research Congress 2014. Atlanta, Georgia, USA.

https://doi.org/10.1061/9780784413517.216

Parkhe, A. (1991). Interfirm diversity, organizational learning, and longevity in global strategic alliances. Journal of International Business Studies, 22, 579-601.

https://doi.org/10.1057/palgrave.jibs.8490315

Polit, D. F., \& Beck, C. T. (2004). Nursing research: Principles and methods. Lippincott Williams \& Wilkins.

Price, A. D. F., \& Newson, E. (2003). Strategic management: Consideration of paradoxes, processes, and associated concepts as applied to construction. Journal of Management in Engineering, 19(4), 183-192.

https://doi.org/10.1061/(ASCE)0742-597X(2003)19:4(183)
Rutihinda, C. (2008). Factors influencing the internationalization of small and medium size enterprises. International Business \& Economics Research Journal, 7(12), 45-53. https://doi.org/10.19030/iber.v7i12.3312

Sakakibara, M., \& Porter, M. E. (2001). Competing at home to win abroad: evidence from Japanese industry. Review of Economics and Statistics, 83(2), 310-322. https://doi.org/10.1162/00346530151143842

Salaman, G., \& Asch, D. (2003). Strategy and capability: sustaining organizational change. Blackwell Publishing Ltd.

Sambasivan, M., \& Soon, Y. W. (2007). Causes and effects of delays in Malaysian construction industry. International Journal of Project Management, 25(5), 517-526. https://doi.org/10.1016/j.ijproman.2006.11.007

Scherer, F. M., \& Ross, D. (1990). Industrial market structure and economic performance. University of Illinois at UrbanaChampaign's Academy for Entrepreneurial Leadership Historical Research Reference in Entrepreneurship. https://ssrn.com/abstract $=1496716$

Serra, L. A., Pellicer, E., \& Yepes, V. (2017). Method for estimating the social sustainability of infrastructure projects. Environmental Impact Assessment Review, 65, 41-53. https://doi.org/10.1016/j.eiar.2017.02.004

Sierra, L. A., Yepes, V., \& Pellicer, E. (2018). A review of multicriteria assessment of the social sustainability of infrastructures. Journal of Cleaner Production, 187, 496-513. https://doi.org/10.1016/j.jclepro.2018.03.022

Sullivan, D., \& Bauerschmidt, A. (1990). Incremental internationalization: A test of Johanson and Vahlne's thesis. MIR: Management International Review, 30(1), 19-30.

Utama, W. P., Chan, A. P. C., Zahoor, H., \& Gao, R. (2016). Review of research trend in international construction projects: A bibliometric analysis. Construction Economics and Building, 16(2), 71-82. https://doi.org/10.5130/AJCEB.v16i2.4866

Wang, S. Q., Tiong, R. L. K., Ting, S. K., \& Ashley, D. (1999). Political risks: Analysis of key contract clauses in China's BOT project. Journal of Construction Engineering and Management, 125(3), 190-197. https://doi.org/10.1061/(ASCE)0733-9364(1999)125:3(190)

Watt, D. J., Kayis, B., \& Willey, K. (2010). The relative importance of tender evaluation and contractor selection criteria. International Journal of Project Management, 28(1), 51-60. https://doi.org/10.1016/j.ijproman.2009.04.003

Welch, D. E., Welch, L. S., \& Marschan-Piekkari, R. (2001). The persistent impact of language on global operations. Prometheus, 19(3), 193-209. https://doi.org/10.1080/08109020110072180

Winch, G. M. (2008). Internationalisation strategies in businessto-business services: The case of architectural practice. Service Industries Journal, 28(1), 1-13. https://doi.org/10.1080/02642060701725347

Wu, C. L., Fang, D. P., Liao, P. C., Xue, J. W., Li, Y., \& Wang, T. (2015). Perception of corporate social responsibility: The case of Chinese international contractors. Journal of Cleaner Production, 107, 185-194. https://doi.org/10.1016/j.jclepro.2015.04.143

Xia, B., Chan, A., Molenaar, K., \& Skitmore, M. (2012). Determining the appropriate proportion of owner-provided design in design-build contracts: Content analysis approach. Journal of Construction Engineering and Management, 138(9), 10171022. https://doi.org/10.1061/(ASCE)CO.1943-7862.0000522 
Xiaopeng, D., \& Pheng, L. S. (2013). Understanding the critical variables affecting the level of political risks in international construction projects. KSCE Journal of Civil Engineering, 17, 895-907. https://doi.org/10.1007/s12205-013-0354-5

Yalegama, S., Chileshe, N., \& Ma, T. (2016). Critical success factors for community-driven development projects: A Sri Lankan community perspective. International Journal of Project Management, 34(4), 643-657.

https://doi.org/10.1016/j.ijproman.2016.02.006

Yang, H., Chan, A. P. C., \& Yeung, J. F. Y. (2015). Niche width, competitive positioning, and performance of international construction contractors (1992-2009). Journal of Management in Engineering, 31(3), 04014040.

https://doi.org/10.1061/(ASCE)ME.1943-5479.0000250

Ye, K., Lu, W., \& Jiang, W. (2009). Concentration in the international construction market. Construction Management and Economics, 27(12), 1197-1207. https://doi.org/10.1080/01446190903222429

Yildiz, A. E., Dikmen, I., Birgonul, M. T., Ercoskun, K., \& Alten, S. (2014). A knowledge-based risk mapping tool for cost estimation of international construction projects. Automation in Construction, 43, 144-155.

https://doi.org/10.1016/j.autcon.2014.03.010

Yitmen, I. (2013). Organizational cultural intelligence: A competitive capability for strategic alliances in the international construction industry. Project Management Journal, 44(4), 5-25. https://doi.org/10.1002/pmj.21356
Zafar, S., Tabish, S., \& Jha, K. N. (2012). Success traits for a construction project. Jornal of Construction Engineering and Management, 138(10), 1131-1138.

https://doi.org/10.1061/(ASCE)CO.1943-7862.0000538

Zhao, Z.-Y., Tang, C., Zhang, X., \& Skitmore, M. (2017). Agglomeration and competitive position of contractors in the international construction sector. Journal of Construction Engineering and Management, 143(6), 04017004. https://doi.org/10.1061/(ASCE)CO.1943-7862.0001284

Zhao, Z. Y., \& Shen, L. Y. (2008). Are Chinese contractors competitive in international markets? Construction Management and Economics, 26(3), 225-236. https://doi.org/10.1080/01446190801905380

Zhao, Z. Y., Shen, L. Y., \& Zuo, J. (2009). Performance and strategy of Chinese contractors in the international market. Journal of Construction Engineering and Management, 135(2), 108-118. https://doi.org/10.1061/(ASCE)0733-9364(2009)135:2(108)

Zhao, Z. Y., Xu, K., Zuo, J., \& Tang, C. (2016). Developing the international construction contracting market: Enterprise niche approach. Journal of Management in Engineering, 33(1), 04016027. https://doi.org/10.1061/(ASCE)ME.1943-5479.0000470

Zich, R. (2014). An analysis of terminology of concepts of competitiveness in the presentations of strategic development of selected car manufacturers. Central European Journal of Management, 1(1), 13-24. https://doi.org/10.5817/CEJM2014-1-2 